\title{
Detection of Latent Infections of Ralstonia solanacearum Race 3 Biovar 2 in Geranium
}

\author{
Jill K. Swanson, Department of Plant Pathology, University of Wisconsin-Madison, Madison 53706; Luis Montes \\ and Luis Mejia, Faculty of Agronomy, University of San Carlos, Guatemala City, Guatemala; and Caitilyn Allen, \\ Department of Plant Pathology, University of Wisconsin-Madison
}

\begin{abstract}
Swanson, J. K., Montes, L., Mejia, L., and Allen, C. 2007. Detection of latent infections of Ralstonia solanacearum race 3 biovar 2 in geranium. Plant Dis. 91:828-834.

Ralstonia solanacearum race 3 biovar 2 is a regulated quarantine pathogen that infects solanaceous hosts such as potato as well as geranium, where it causes either bacterial wilt (also known as Southern Wilt) or a symptomless latent infection. Geranium growers and government regulators need reliable detection methods to identify infected plant material before it is exported. We previously found that $R$. solanacearum-infected geranium plants can shed millions of bacteria in effluent water that flows from pots. We tested a nondestructive sampling method wherein effluent water from infected plants grown under commercial conditions was both dilution plated and filter concentrated for real-time polymerase chain reaction (PCR). Under field conditions in Guatemala, effluent shedding of infected geranium plants was highly variable. Comprehensive growth chamber studies confirmed that latently infected and mildly symptomatic geranium plants often but not invariably shed detectable numbers of bacteria in their effluent. At the peak of bacterial shedding, just under $90 \%$ of infected plants shed detectable bacteria whereas, at the lowest point, $44 \%$ shed detectable numbers of pathogen cells. Bacterial shedding peaked several weeks after inoculation regardless of whether plants were symptomatic or latently infected. Bacterial stem population sizes did not correlate with either effluent population sizes or disease index rating. Finally, we found that the effluent from geranium plants grown in volcanic rock scoria medium contains inhibitors that reduce the effectiveness of real-time PCR detection methods.
\end{abstract}

Additional keywords: brown rot, Pelargonium $\times$ hortorum

Ralstonia solanacearum (Smith) Yabuuchi et al., the causal agent of bacterial wilt disease, is a gram-negative, soil-dwelling bacterium that enters its host through the roots and colonizes the xylem tissue. Symptoms of infection include yellowing, wilting, vascular browning, and eventual plant death. $R$. solanacearum is a species complex (9) that causes bacterial wilt diseases in over 200 plant species, including vegetable crops such as potato and tomato, cash crops such as tobacco, and several ornamentals, including hydrangea and geranium (where it is also known as Southern Wilt disease; 11,12,14,16,17,26). This pathogen can be found on six of the seven continents (9). It is most destructive in tropical and subtropical regions, but also has caused persistent problems in more temperate climates, including the United States and Europe (5). As is often the case with soilborne bacterial plant pathogens, control methods are limited and those

Corresponding author: C. Allen

E-mail: cza@plantpath.wisc.edu

Accepted for publication 31 January 2007.

doi:10.1094/PDIS-91-7-0828

(C) 2007 The American Phytopathological Society available are not very effective (23). Because of its broad host range, wide geographical distribution, and limited control measures, this pathogen can cause severe crop losses (7). An example is brown rot of potato, usually caused by the race 3 biovar 2 (R3bv2) subgroup of $R$. solanacearum. This group is reportedly more cool tolerant than other strains and is more often found in tropical highlands and temperate zones where potato is grown $(1,4)$. Infection leads to wilted plants and rotting tubers, a devastating result for farmers, especially in developing countries where potato provides a major food source.

$R$. solanacearum also easily forms latent infections, where host stems contain large bacterial populations but symptoms are not visible. This is common on potato, where cool growing conditions often suppress symptom development (1); however, latent infection also has been reported on "resistant" cultivars (10), weedy hosts such as Solanum dulcamara (6), and ornamentals, specifically geranium (Pelargonium $\times$ hortorum). We previously found that between 12 and $26 \%$ of soil-inoculated geranium plants harbored latent infections (24). Stem populations of $R$. solanacearum in latently infected plants can reach $10^{9}$ $\mathrm{CFU} / \mathrm{g}$ of host tissue, although bacteria are not evenly distributed throughout the plant.
The ability of $R$. solanacearum to establish latent infections in geranium has become a serious problem for the floriculture industry. Geranium cuttings exported to North America and Europe are grown primarily in greenhouses in the highlands of Africa and Central America where R. solanacearum is endemic. Geranium plants are propagated vegetatively by taking cuttings from large potted plants, known as mother plants. These soil-free cuttings are exported, rooted, finished to a flowering state, and eventually sold in garden centers. In the 6 to 12 months that a mother plant is used, it will produce 20 to 35 cuttings, averaging about 2 cuttings per week (M. Klopmeyer, personal communication). If the mother plant is infected, the cuttings also may harbor bacteria and can serve as a source of inoculum in specialty rooting stations and greenhouses, where the pathogen can spread quickly through irrigation water.

$R$. solanacearum R3bv2 accidentally was imported into the United States and Europe in geranium cuttings in 1999 $(15,26)$, but the problem did not have a major impact in the United States until 2003 and 2004, when geranium plants imported from Kenya, Costa Rica, and Guatemala developed bacterial wilt disease in U.S. greenhouses and nurseries. These outbreaks were caused by R3bv2, which was listed on the Agricultural Bioterrorism Protection Act of 2002 because of its potential impact on the U.S. potato industry (20). As a listed "Select Agent," the pathogen was subject to strict eradication and quarantine requirements, which led to the destruction of millions of geranium plants at a cost of over $\$ 10$ million (M. Klopmeyer, personal communication). Geranium propagators take phytosanitary measures to prevent the introduction of $R$. solanacearum into their production greenhouses, including sterilizing cutting knives between plants, disinfectant footbaths, worker education, and clean irrigation water. However, the United States Department of Agriculture APHIS requires ongoing monitoring of geranium for infection with $R$. solanacearum because of the importance of this pathogen. Because the bacteria live in the xylem tissue and are unevenly distributed throughout the plant (24), the only reliable detection method has been destructive sampling. In production, plants are sampled by maceration of 
stem and root tissue followed by immunological strip testing. Sampling occurs weekly and 1 plant per 50,000 (with a minimum of 10) are tested (2). This process is time consuming and ineffective. It allows for sampling of a small, statistically nonrepresentative number of plants, and the detection sensitivity of the immunological strips in infected plant material is about $1 \times 10^{5}$ cells (J. Swanson, unpublished results). A better, more sensitive diagnostic method is needed to allow growers and APHIS regulators to be confident that $R$. solanacearum-free cuttings are being shipped.

$R$. solanacearum is often abundantly shed from the roots of infected plants (19). Initial studies found that young geranium plants grown in peat-based potting mix shed an average of $2 \times 10^{6}$ and $1 \times 10^{5}$ $\mathrm{CFU} / \mathrm{ml}$ from symptomatic and latently infected plants, respectively (24). This finding suggested a diagnostic method in which effluent water (run-off) from geranium plants in production greenhouses could be filtered and the filters tested for the presence of the pathogen with $R$. solanacearum-specific real-time polymerase chain reaction (PCR) primers (24). However, the geranium mother plants used in production are much larger than those in the initial study, and they are grown in steam-sterilized volcanic scoria rock fragments rather than peat mix. Could effluent monitoring be an effective and reliable tool for certifying a greenhouse as $R$. solanacearum-free, thus preventing the export of the pathogen on geranium cuttings? The goal of this study was to determine if large, infected geranium plants grown in scoria reliably shed detectable numbers of bacteria from their roots into effluent water, and to define the relationship of this phenomenon to symptom development and disease severity. Finally, we tested the effluent filtering and real-time PCR method to measure the sensitivity of this diagnostic method.

\section{MATERIALS AND METHODS}

Bacterial strains and growth. UW551rif, a spontaneous rifampicin-resistant R3bv2 strain of $R$. solanacearum, was used in this study (24). $R$. solanacearum strains were grown routinely in CPG broth (13) at $28^{\circ} \mathrm{C}$ with shaking at $250 \mathrm{rpm}$ for aeration. To grow pure cultures on solid medium, we used CPG plus $1.8 \%$ agar and $0.05 \%$ 2,3,5-triphenyltetrazolium chloride (TZC) (18). Extracts from plants were plated on modified SMSA semiselective medium (8) without the polymyxin B sulfate and with rifampicin at $50 \mu \mathrm{g} / \mathrm{ml}$ to select UW551-rif. The mucoid and irregularly shaped $R$. solanacearum-typical colonies were counted after incubation for 48 to $72 \mathrm{~h}$ at $28^{\circ} \mathrm{C}$.

Preliminary on-site screenhouse experiments in Guatemala. Geranium plants (cv. Designer Dark Red) were transported from the Floricultura \& Cia. Ltda. production facilities (Ball Horticultural Co.) in Jalapa, Guatemala to a screened greenhouse at the Universidad de San Carlos in Guatemala City, Guatemala. The plants were grown in 6-liter heavy plastic bags with drainage holes. Each bag contained two plants grown in volcanic scoria (steam sterilized prior to use). Geranium plants were watered daily with a proprietary fertilizer solution as used during commercial production and given 10 days to recover from transport before inoculation. Temperatures were uncontrolled and, therefore, varied substantially with the weather. Recorded temperatures varied from $13^{\circ} \mathrm{C}$ in the early morning to $41^{\circ} \mathrm{C}$ at midday. For the screenhouse experiments, 14 plants contained in seven bags were inoculated with 10,000 CFU/plant directly onto the wound created when a petiole was removed from the lower stem. Sixteen plants contained in eight bags were inoculated in the same manner with 500 CFU/plant. On days 13, 14, and 15 after inoculation, the first $5 \mathrm{ml}, 30$ to $45 \mathrm{ml}$, and 100 to $200 \mathrm{ml}$ of effluent, respectively, were collected by running the irrigation system and immediately collecting the resulting effluent in plastic bags beneath each potting bag. On days 14 and 15, effluent also was collected from uninoculated control plants to serve as a negative control and for dilution of samples. Effluent from each day was dilution plated on modified SMSA medium for bacterial enumeration. Effluent also was pooled, diluted, and filtered, and the filters were sent to the United States for PCR analysis as described below. At 19 days after inoculation, each plant was cut at the soil line. Approximately $1 \mathrm{~g}$ of crown tissue was weighed, ground in $5 \mathrm{ml}$ of water, and dilution plated to test for infection and population size as described below. The experiment was conducted twice more on 20 plants, each inoculated with approximately 5,000 CFU/plant. The effluent was monitored occasionally, and the plants were harvested either 34 or 47 days post inoculation.

Geranium growing conditions and inoculations for growth chamber studies. Geranium plants (cv. Designer Dark Red) were grown on site at Ball FloraPlant greenhouse facilities (West Chicago, IL) from rooted cuttings in 6-in. $(15 \mathrm{~cm})$ pots of steam-sterilized volcanic scoria imported from Guatemala. Eight weeks after transplantation, geranium plants were transported to the growth chamber and incubated at $24^{\circ} \mathrm{C}$ for $14 \mathrm{~h}$ of light and $19^{\circ} \mathrm{C}$ for $10 \mathrm{~h}$ of dark. The geranium plants were allowed at least 2 weeks to recover from transportation before inoculation. Geranium plants were watered twice daily with Peter's Geranium Special 15-15-15 fertilizer mixed to $225 \mathrm{ppm}$ total nitrogen (Scotts, Marysville, $\mathrm{OH}$ ).

To prepare inoculum, overnight cultures of $R$. solanacearum strains were pelleted and resuspended in water. Inoculum cell densities were determined by dilution plating. For inoculation, a lower leaf was snapped off at the stem, generating an open wound where the petiole had been attached (petiole scar). In experiment 1 , a $2-\mu$ l droplet of $R$. solanacearum suspension containing either 50,500 , or 5,000 cells was applied to the petiole scar of 10 plants for each dose; this droplet was immediately absorbed into the stem. The plants were inoculated in a similar fashion for experiment 2, except that an inoculum of about 1,000 cells per plant was used because no differences in infection rate, stem populations, or effluent populations were seen across the different inoculum levels in experiment 1 . Plants were monitored regularly for wilt symptoms and effluent was collected from plants at various disease stages. Plant disease symptoms were rated on a 0 -to- 5 scale, where $0=$ no symptoms, $1=$ signs of plant stress (leaf yellowing), $2=1$ to $33 \%$ of leaves wilted or chlorotic, $3=34$ to $66 \%$ of leaves wilted or chlorotic, $4=67$ to $100 \%$ of leaves wilted or chlorotic, and $5=$ plant completely wilted and decaying. All growth chamber experiments were conducted at Biosafety Level 2-P, in compliance with Federal regulations and within the University of Wisconsin-Madison Institutional Biosafety Committee stipulations.

Measuring $R$. solanacearum population sizes. We measured $R$. solanacearum populations in effluent water and crown tissue from inoculated geranium plants. To obtain effluent water, geranium pots were placed on two glass rods over a sterile petri dish. Fertilizer solution was poured over the scoria until 15 to $40 \mathrm{ml}$ of effluent flowed from the bottom of the pot into the petri dish. A portion of the effluent was dilution plated on SMSA with rifampicin. Plates containing fewer than 10 colonies, including those with 0 colonies, were considered under the limit of detection and are represented as $<100 \mathrm{CFU} / \mathrm{ml}$ in Table 1 and assigned a value of 100 for figures and in calculations of average population sizes. The remaining effluent was diluted 10 -fold with $R$. solanacearum-free, nonsterile deionized water to simulate the pooling of one infected plant with nine uninfected ones. Aliquots $(100 \mathrm{ml})$ of the dilution were filtered through a $2.0-\mu \mathrm{m}$ prefilter followed by a $0.4-\mu \mathrm{m}, 37-\mathrm{mm}$ polycarbonate filter (Millipore, Billerica, MA) using a syringe. The polycarbonate filter was air dried and placed in a $1.7-\mathrm{ml}$ microcentrifuge tube along with $100 \mu \mathrm{l}$ of sterile, deionized water. The filter was pressed to the bottom of the tube with a sterile wooden applicator and the tube was submerged in a sonicating water bath and sonicated for 5 min. The tube was centrifuged to collect the water and $10 \mu \mathrm{l}$ was used for real-time PCR analysis according to previously described methods (25) using the RS primers and probe and a Bio-Rad iCycler IQ real- 
time PCR machine (Bio-Rad Laboratories, Hercules, CA). For real-time quantification, a standard curve was created using filters made from $100 \mathrm{ml}$ of 10 -fold serial dilutions of water containing UW551-rif at $10^{6}, 10^{5}, 10^{4}, 10^{3}$, and $10^{2} \mathrm{CFU} / \mathrm{ml}$. For all controls and samples, two filters were made from each dilution. For each filter, two real-time PCR samples were quantifour data points. Bacterial DNA on the control filter made from the $1 \times 10^{3}$ $\mathrm{CFU} / \mathrm{ml}$ suspension was reliably detected using this method, although the $1 \times 10^{2}$ $\mathrm{CFU} / \mathrm{ml}$ filters usually were below the limit of detection.

Quantifying bacteria from plant tissue. On day 67 after inoculation, the 20 symptomatic plants in experiment 1 were harvested to determine the population of $R$. solanacearum in the stem. The remaining 10 were held until harvesting on day 96 to observe symptom development. The last effluent sampling for all 30 plants was 65 days after inoculation. On days 72 to 73 after inoculation for experiment 2, all 30 fied and the results were averaged using all

plants were harvested. A slice of crown tissue was harvested from infected plants, weighed, and ground with a mortar and pestle in sterile deionized water. The resulting suspension was serially diluted and plated on modified SMSA plus rifampicin for bacterial enumeration. Sample weight, dilution factor, and plate counts were used to calculate $\mathrm{CFU} / \mathrm{g}$ of tissue. Plates containing fewer than 10 colonies were considered below the limit of detection and are represented in graphs and calculations as $1,000 \mathrm{CFU} / \mathrm{g}$ and in tables as $<1,000$ CFU/g. (The limit of detection is 10 -fold higher for plant tissue than effluent due to differences in original sample size.)

\section{RESULTS}

Preliminary field tests found variable populations of $R$. solanacearum UW551rif in the effluent of scoria-grown geranium plants. We collected effluent from petiole-inoculated geranium plants growing under commercial screenhouse production conditions in Guatemala, and tested for bacterial populations 13,14 , and 15

Table 1. Populations of Ralstonia solanacearum in the crown tissue and effluent water of 30 scoriagrown geranium plants in a preliminary screenhouse study in Guatemala ${ }^{\mathrm{a}}$

\begin{tabular}{|c|c|c|c|c|}
\hline \multirow[b]{2}{*}{ Plant ID } & \multirow[b]{2}{*}{ Crown population ${ }^{c}$} & \multicolumn{3}{|c|}{ Effluent population ${ }^{b}$} \\
\hline & & Day 13 & Day 14 & Day 15 \\
\hline A-1 & 7.53 & 2.76 & 3.63 & 4.11 \\
\hline A-2 & $>10.13$ & & & $\ldots$ \\
\hline B-1 & $>10.13$ & 2.43 & 2.05 & $<2.00$ \\
\hline B-2 & $>10.13$ & & & \\
\hline C-1 & 9.79 & $<2.00$ & $<2.00$ & $<2.00$ \\
\hline $\mathrm{C}-2$ & 9.02 & & & \\
\hline D-1 & $>10.13$ & 4.18 & 5.05 & 4.91 \\
\hline D-2 & $>10.13$ & $\ldots$ & $\ldots$ & $\ldots$ \\
\hline E-1 & 8.79 & 5.65 & 4.23 & 5.05 \\
\hline E-2 & 8.84 & $\ldots$ & $\ldots$ & $\ldots$ \\
\hline F-1 & 8.90 & $<2.00$ & $<2.00$ & $<2.00$ \\
\hline $\mathrm{F}-2$ & 3.78 & & & \\
\hline G-1 & 10.00 & $<2.00$ & 2.30 & 4.37 \\
\hline G-2 & 8.24 & & & $\ldots$ \\
\hline H-1 & 2.56 & $<2.00$ & $<2.00$ & $<2.00$ \\
\hline $\mathrm{H}-2$ & $>10.13$ & & $\cdots$ & $\ldots$ \\
\hline I-1 & 7.88 & $<2.00$ & $<2.00$ & $<2.00$ \\
\hline $\mathrm{I}-2$ & 9.82 & $\ldots$ & $\ldots$ & $\ldots$ \\
\hline $\mathrm{J}-1$ & $>10.13$ & $<2.00$ & 4.04 & 4.49 \\
\hline $\mathrm{J}-2$ & $>10.13$ & & & \\
\hline $\mathrm{K}-1$ & 3.74 & $<2.00$ & $<2.00$ & $<2.00$ \\
\hline $\mathrm{K}-2$ & 2.36 & & & \\
\hline L-1 & 7.86 & $<2.00$ & $<2.00$ & $<2.00$ \\
\hline L-2 & 3.63 & $\ldots$ & $\ldots$ & $\ldots$ \\
\hline M-1 & 7.08 & $<2.00$ & $<2.00$ & $<2.00$ \\
\hline M-2 & 4.26 & (n) & $\ldots$ & $\ldots$ \\
\hline $\mathrm{N}-1$ & $<3.00$ & $<2.00$ & $<2.00$ & $<2.00$ \\
\hline $\mathrm{N}-2$ & $<3.00$ & & & $\ldots$ \\
\hline $\mathrm{O}-1$ & 8.35 & $<2.00$ & 4.95 & 4.97 \\
\hline $\mathrm{O}-2$ & $>10.13$ & $\ldots$ & $\ldots$ & $\ldots$ \\
\hline
\end{tabular}

a Plants were potted two per bag and petiole inoculated; plants A-G with 10,000 CFU/plant and plants $\mathrm{H}-\mathrm{O}$ with $500 \mathrm{CFU} /$ plant. Effluent was sampled on days 13, 14, and 15 post inoculation and crown tissue was harvested 19 days post inoculation.

${ }^{b}$ Bacterial population sizes, given as $\log \mathrm{CFU} / \mathrm{ml}$ of effluent, were determined by dilution plating pot effluent water on semiselective SMSA agar (see Methods for details). The identity of $R$. solanacearum-typical colonies was confirmed by immumostrip testing (Agdia, Inc.); $<2.00$ indicates population size under the limit of detection.

${ }^{\mathrm{c}}$ Bacterial population sizes, given as log CFU/g of plant tissue, were determined by dilution plating ground geranium crown tissue on semiselective SMSA agar (see Methods for details). The identity of $R$. solanacearum-typical colonies was confirmed by immumostrip testing (AgDia, Inc.); $>10.13$ indicates population sizes over the detection limit; $<3.00$ is under the detection limit for this assay. days after inoculation with UW551-rif. At 19 days after inoculation, crown populations for each plant were determined by grinding stem tissue and dilution plating. In 14 of the 15 two-plant bags, UW551-rif was detected in both plants and most had very large bacterial stem populations $(>1 \times$ $10^{7} \mathrm{CFU} / \mathrm{g}$; Table 1). Plants N-1 and N-2, which were planted in the same bag, appeared to have escaped infection. The remaining plant bags had variable effluent populations. Despite containing infected plants, seven bags (14 plants) never released detectable bacteria in their effluent, with a detection limit of $100 \mathrm{CFU} / \mathrm{ml}$. Of the remaining seven bags, only three released detectable bacterial populations on all three sampling days; the remaining four had significant populations in only two of the three samples (Table 1).

Two additional similar experiments were conducted in the screenhouse in Guatemala with poor infection success, possibly as a result of temperature variability. However, in these experiments, stem populations also did not predict effluent population size (data not shown.) Because of this erratic disease development and logistical difficulties, the experiments were continued in a controlled growth chamber.

Populations of $R$. solanacearum UW551-rif in the effluent of scoria-grown geranium were variable under growthchamber conditions, but increased with disease index until plant death. We performed two separate growth-chamber experiments, each involving 30 large geranium plants grown in pots of volcanic scoria. The plants were inoculated, monitored for bacterial effluent populations and disease symptoms, and eventually harvested to determine the bacterial stem population size. Of the 60 plants in these two experiments, four plants $(6.7 \%)$ apparently escaped infection and had no detectable bacteria in their effluent or stems. Ten of the plants (16.7\%) showed no disease symptoms until at least 65 days after inoculation, but did carry large stem populations of the pathogen. These were considered latently infected. Effluent populations from these latently infected plants were variable. Two of the latent plants had no detectable effluent populations at any sampling, whereas several had detectable numbers at nearly every sampling (Fig. 1). Overall, the effluent populations of plants with a disease index (DI) of 0 to 2 (plants with no visible symptoms to slight symptom development) ranged from undetectable in many cases to $7.17 \times 10^{5} \mathrm{CFU} / \mathrm{ml}$ at the highest (Fig. 2). This variability decreased, however, as symptoms developed. Although highly variable at DIs of 0 , 1 , and 2, plants with a disease index of 3 had detectable effluent populations at every effluent collection across both experiments. The average bacterial population size in the effluent followed a similar pattern, increasing through a DI of 0 to 3 , 
then decreasing at a DI of 4 and 5 (Fig. 2). At a DI of 5 (dead and decaying), the effluent of most plants contained no detectable $R$. solanacearum cells.

Bacterial effluent shedding from infected plants peaked several weeks after inoculation. In both growth-chamber experiments, there was a delay between plant inoculation and bacterial shedding into the effluent. In experiment 2, only $48.3 \%$ of all the infected plants had detectable effluent populations at the first sampling on day 16 after inoculation. This was the lowest incidence of all of the sampling dates. The percentage of infected plants shedding detectable numbers of bacteria peaked over days 37 and 43, with $89.7 \%$ detection (Fig. 3 ). This was the highest incidence of effluent detection of any single sampling in either growth chamber experiment. Overall, the average incidence of bacterial shedding from infected plants was $71.0 \%$ for experiment 2 . When we eliminated the highly symptomatic plants from the analysis and considered only those geranium plants that had slight or no symptoms (DI $=0$ to 2), we found a similar range (44.4 to $83.3 \%)$ and average incidence of detection (67.2\%) (Fig. 3). The patterns of effluent shedding for experiments 1 and 2 were similar (data not shown), although effluent shedding peaked slightly later in experiment 2. Overall, the average number of infected plants with detectable effluent populations of all samplings in experiments 1 and 2 was $70.6 \%$.

Population sizes of $R$. solanacearum in crown tissue did not directly correlate with either effluent populations or disease index. At the end of each growthchamber experiment, we took a final sample of effluent and then dilution plated ground crown tissue to determine the bacterial population size in each plant stem. Bacterial population sizes in the effluent did not predict the crown population sizes (Fig. 4A). In fact, whereas most plant stem populations ranged fairly narrowly from $10^{7}$ to $10^{9}$ $\mathrm{CFU} / \mathrm{g}$ of stem tissue, the effluent populations were anywhere from below detection level to about $10^{6} \mathrm{CFU} / \mathrm{ml}$. The linear trend line comparing stem populations to effluent populations of plants with a disease index of 0 to 4 (omitting the DI $=5$ dead and decaying plants) does not predict results, with an $R^{2}$ value of only 0.19 (Fig. 4A).

We also compared the stem population sizes with the DI of the plant at the time of harvest. Excluding the four plants that escaped infection, all plants with a disease index between 0 and 3 harbored stem populations of $R$. solanacearum of between $6.6 \times 10^{6}$ and $2 \times 10^{9} \mathrm{CFU} / \mathrm{g}$ (Fig. 4B). Although plants with a DI of 4 and 5 generally contained similar stem populations, the population sizes in eight of these plants were below $10^{6} \mathrm{CFU} / \mathrm{g}$, with two below the detection level.

Real-time PCR analysis of effluent filters did not reliably detect the presence of bacteria. During experiment 2, we used effluent samples from each plant to perform real-time PCR at three different sampling times: days 22 to 23 , days 43 to 44 ,

and days 72 to 73 . Diluted effluent (100 $\mathrm{ml}$ ) was passed through a polycarbonate filter and the filter rinsate was analyzed for the presence of $R$. solanacearum using a

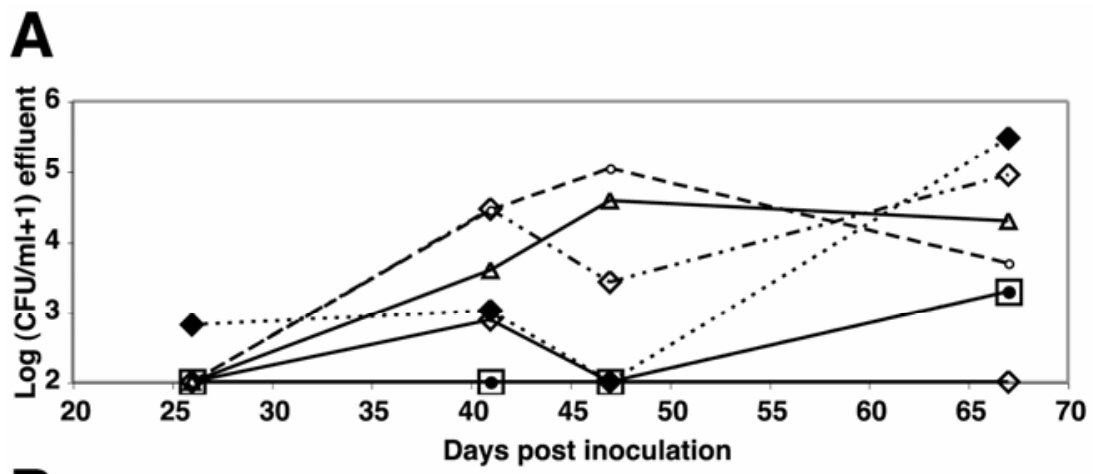

B

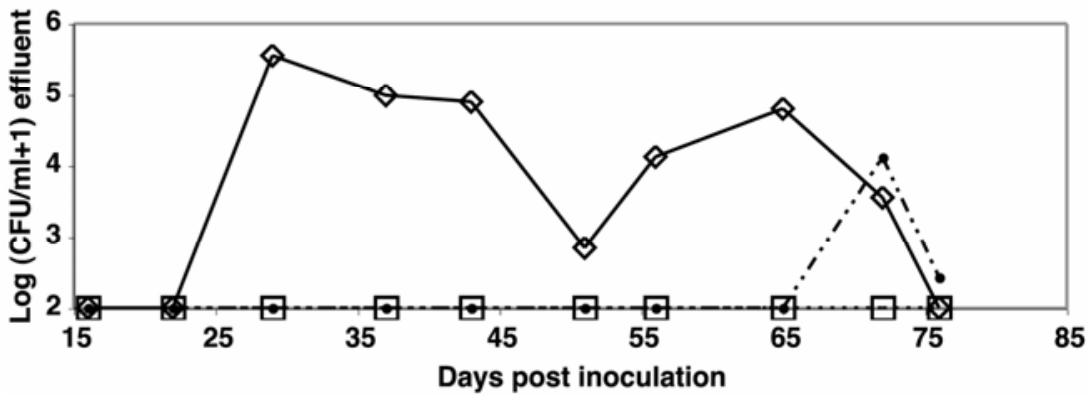

Fig. 1. Ralstonia solanacearum race 3 biovar 2 population sizes over time in effluent from individual latently infected geranium plants grown in the growth chamber. Effluent from pots containing plants growing in volcanic scoria was collected and dilution plated to enumerate bacteria $\mathbf{A}$, at four time points for experiment 1 and $\mathbf{B}$, once weekly for 10 weeks for experiment 2 . All plants subsequently were confirmed to be infected with $R$. solanacearum.

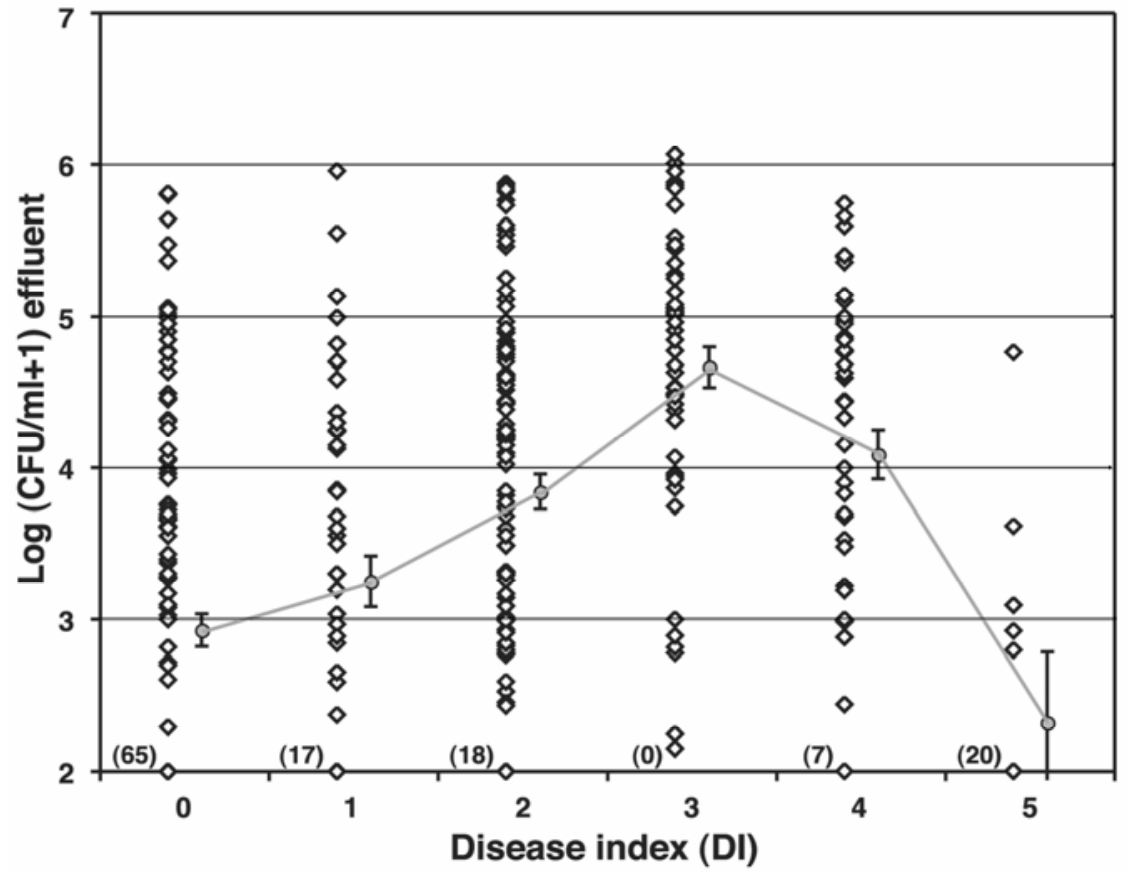

Fig. 2. Relationship between disease index and Ralstonia solanacearum race 3 biovar 2 population sizes in effluent from infected geranium plants. The effluent from infected geranium plants was collected and dilution plated repeatedly over the course of two experiments. Each diamond represents the effluent population of a single plant at the time of sampling, sorted by the plant's disease index rating at time of sampling. Gray circles show the mean effluent population size for each disease index. Numbers in parentheses report the number of points under the limit of detection. Bars represent the standard error of the mean. 
Taqman real-time PCR assay. Threshold crossings from these effluent filters were compared with those from a standard curve generated with filters containing known numbers of UW551-rif cells. In total, we tested 63 plants with detectable effluent populations by plating and, of these, 37 were detectable by real-time PCR whereas 26 were not. The average effluent population (calculated by dilution plating) for those that were detected by real-time PCR was $2 \times 10^{5} \mathrm{CFU} / \mathrm{ml}$, with a range of $1.0 \times$ $10^{3}$ to $1.2 \times 10^{6}$. The average effluent population for those filters that went undetected by real-time PCR was $3.7 \times 10^{4}$ $\mathrm{CFU} / \mathrm{ml}$, with a range of $1.65 \times 10^{2}$ to 4.6 $\times 10^{5} \mathrm{CFU} / \mathrm{ml}$. We also compared realtime PCR results from filters made from either effluent water from uninoculated geranium plants or distilled water that both had been spiked with similar bacterial populations. We found that the filters made from effluent had lower threshold crossings than the spiked water controls, which could always be detected at $1 \times 10^{3}$ $\mathrm{CFU} / \mathrm{ml}$ (data not shown). This result suggests that geranium effluent contains inhibitors of the real-time PCR reaction.

\section{DISCUSSION}

When $R$. solanacearum R3bv2 causes wilting, necrosis, and plant death, the presence of the bacterium is obvious and can nological methods or PCR $(3,8,25)$. However, in many plants, including potato, tomato bred for resistance, and some ornamentals, the pathogen can multiply to high numbers without causing symptoms. The trigger or triggers of such latent infections are not well understood, although they are likely the result of several interbe verified easily using either immu-

acting factors, including plant response and environmental conditions. This absence of symptoms increases the risk of pathogen dispersal. Latently infected potato tubers may have been the source of the European outbreak of $R$. solanacearum R3bv2 and latently infected geranium cuttings probably were responsible for several accidental introductions of R3bv2 into North America and Europe $(14,15,26)$. However, the exhaustive destructive sampling necessary to reliably detect low levels of latent infection among valuable ornamental mother plants is not economically feasible. Thus, nondestructive and sensitive methods of pathogen diagnosis are urgently needed.

Diagnosis of $R$. solanacearum in geranium production facilities continues to be a problem for the geranium industry. The current random immunological sampling method is both inefficient and unreliable. Although the immunostrips can detect $10^{5}$ CFU in plant material, good enough to detect most infected plants, this laborintensive and destructive plant-by-plant approach can sample only a small percentage of the total plants, making identification of an isolated latent infection very unlikely. In our previous studies, we found that small, peat-mix-grown geranium plants shed large numbers of bacteria in their effluent when infected with $R$. solanacearum. Although this phenomenon likely is responsible for pathogen dispersal, we hypothesized that it also could be exploited to monitor and detect infected geranium plants in a greenhouse setting. We set out to determine if large scoria-grown geranium plants infected with $R$. solanacearum R3bv2 reliably shed bacteria in their effluent and if this

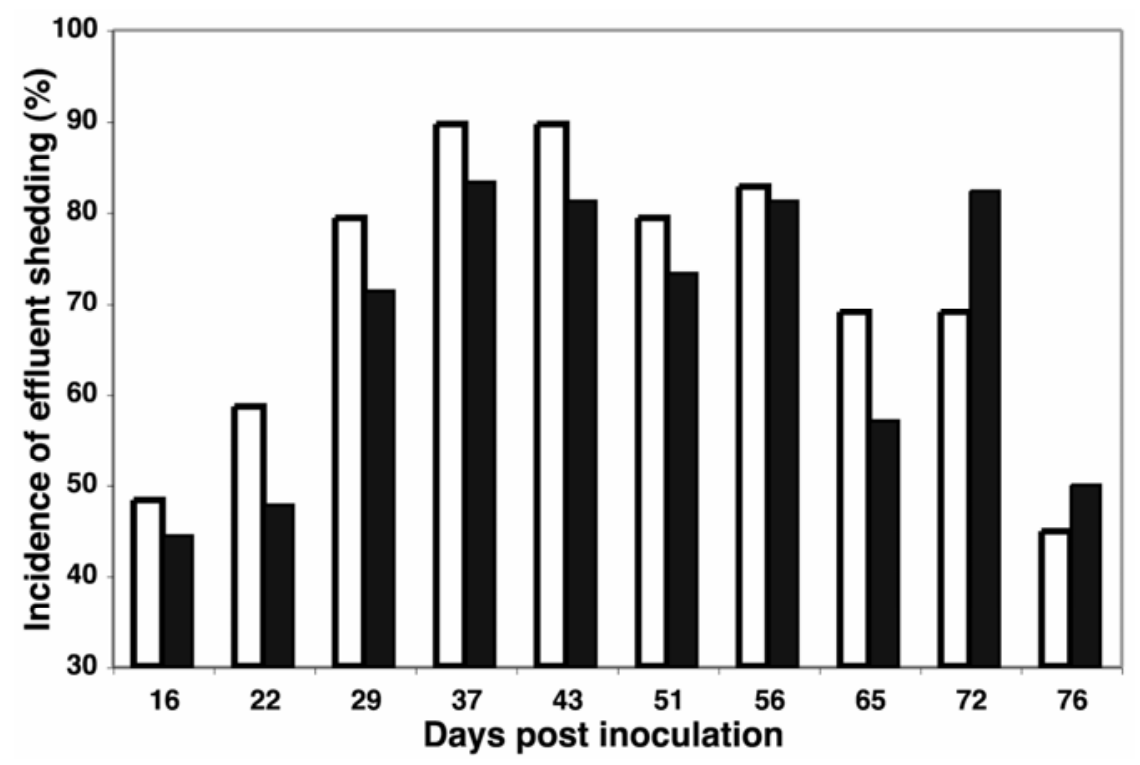

Fig. 3. Percentage of infected geranium plants that produced detectable numbers of Ralstonia solanacearum in effluent during growth-chamber experiment 2. Pathogen population sizes in the effluent of petiole-scar-inoculated geranium plants were monitored weekly. Open bars include all infected plants, while the black bars represent only plants with a disease index of 0,1 , and 2 (latently infected and mildly symptomatic). occurred regardless of symptom development.

Because growth chamber experiments do not always accurately reflect the behavior of a pathogen in the field, we conducted initial experiments in a screenhouse in Guatemala under production conditions, which include the rhizosphere microbial communities present in tropical greenhouses. Our preliminary studies gave variable results. Plants in all but one of the inoculated bags became infected but only half shed detectable numbers of bacteria. Three bags shed reliably at every sampling, four bags were variable, and seven bags never shed bacteria in detectable numbers. Unfortunately, due to time constraints, we were able to sample only up to 15 days after inoculation. Our growthchamber studies suggest that bacterial shedding in the effluent peaks several weeks after inoculation. Therefore, our screenhouse geranium plants likely would have shed more bacteria if they had been
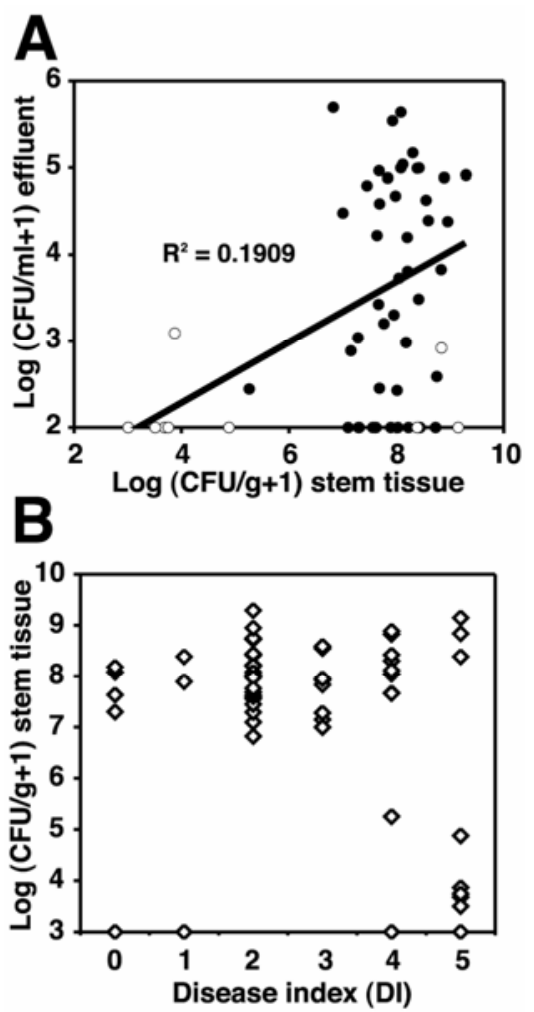

Fig. 4. Relationship of pathogen stem population sizes at end of experiment with plant disease index and with the Ralstonia solanacearum population size in the plant's effluent. Crown tissue from geranium plants was ground and dilution plated on day 67 or day 96 (see Methods) for experiment 1 and on days 72 and 73 for experiment 2. A, $R$. solanacearum stem population sizes are graphed against effluent population sizes shortly before harvest. Filled circles represent plants with a disease index of 0 to 4 . Open circles represent plants with a disease index of 5 (dead or decaying). The line is the best-fit logarithmic trendline. B, $R$. solanacearum stem population sizes are graphed against disease index at the time of harvest. Each symbol represents an individual plant. 
sampled in later weeks. However, these results suggested that an $R$. solanacearum infection is not invariably signaled by bacteria in the effluent.

We also collected and plated effluent from infected growth-chamber-grown geranium plants over many weeks and then harvested the stem tissue to test for the presence of bacteria. Increased inoculum concentrations result in more disease development and fewer latent infections in soil-inoculated geranium plants (24). Because we wanted to test a mixture of latently infected and actively symptomatic plants, we tested three different inoculum levels in experiment 1 . However, the different inoculum levels did not affect either disease development or bacterial efflux ( $\mathrm{J}$. Swanson, unpublished results). The ratio of latently infected plants to symptomatic plants, the disease severity, and the bacterial effluent and stem populations all were independent of the initial inoculum density. Although increasing inoculum did not appear to increase symptom development in these studies, it is possible that a much higher inoculum would have done so. We speculate that inoculum density is less important when the pathogen is introduced directly into the stem because this bypasses natural physical and chemical plant defenses. In fact, petiole inoculation of tomato plants with as few as 100 cells of biovar 1 strain K60 can kill $100 \%$ of inoculated plants (J. Swanson and C. Allen, unpublished observations). Root infection and direct introduction of bacteria to the stem both are possible in geranium production facilities through the use of contaminated irrigation water or knives, respectively.

In both experiments 1 and 2, there was large variability in bacterial population sizes in the effluent of latently infected plants and those with mild symptoms. Some plants with slight to no symptoms did not shed detectable pathogen cells, whereas others shed as many as $7 \times 10^{5}$ $\mathrm{CFU} / \mathrm{ml}$. When the geranium plants had moderate symptoms (DI of 3), all plants shed detectable numbers of bacteria, but effluent population sizes plummeted as disease advanced, probably because $R$. solanacearum competes poorly with the secondary decay microbes that colonize wilting hosts.

It is not known what causes the variability in pathogen effluent population sizes among latently infected geranium plants. Perhaps the ability of $R$. solanacearum to exit the roots depends on the degree of stem colonization and how far the bacteria have been able to spread. If a small, localized infection is contained in only a few vascular bundles, the likelihood of detectable effluent bacteria might be low. Extensive tissue maceration in the stem and root systems may block bacteria from efficiently escaping from plants. $R$. solanacearum may use tactic swimming motility to actively leave host roots, but the regulation of taxis in this organism is complex and poorly understood (27). Whatever the reason, the high variability of bacterial shedding from roots of latently infected plants reduces the appeal of monitoring effluent for diagnostics and detection, because latently infected plants pose the greatest risk for accidental pathogen dissemination.

The likelihood that an infected plant was actively shedding bacteria in its effluent water increased over time, peaking 5 to 6 weeks after inoculation. Assuming that greenhouse workers would remove any moderately or severely symptomatic geranium plants, it is most important to detect infected geranium plants with a disease index of 0 to 2 . At 2 weeks post inoculation, only $44.4 \%$ of these plants were shedding $R$. solanacearum and, at their peak, $83.3 \%$ had detectable effluent populations. Therefore, at any given time, 17 to $65 \%$ of infected geranium plants with no to slight symptoms did not shed detectable bacterial populations in their effluent. These results suggest that latently infected geranium plants potentially could remain in production for up to 65 days before infection is detected through effluent testing.

Bacterial effluent population sizes at the end of the experiments were not well correlated with bacterial crown population sizes $\left(R^{2}=0.19\right)$. Moreover, bacterial stem population sizes appeared independent of disease severity. Finally, we did not detect a significant difference in pathogen stem population sizes between symptomatic and asymptomatic infected geranium plants. Latently infected tomato plants often have smaller stem populations of bacteria, and the cells usually are limited in their lateral spread within the stem (21), but we previously observed that latently infected geranium plants were just as likely as symptomatic plants to contain pathogen cells in their upper stems and leaves (24). More studies are required to better understand the phenomenon of latent infection.

We tested a method of filtering effluent from infected geranium plants to concentrate bacteria, followed by assaying the filters with $R$. solanacearum-specific realtime PCR analysis. This method, which we proposed previously (24), is under consideration for testing effluent from greenhouses in offshore geranium production. We found significant inhibition of the PCR on filters prepared from bacteria-spiked effluent versus filters prepared from bacteria-spiked water. The sensitivity of this method was variable, in some cases detecting as few as $1 \times 10^{3} \mathrm{CFU} / \mathrm{ml}$ of effluent, but in other cases failing to detect $4.6 \times$ $10^{5} \mathrm{CFU} / \mathrm{ml}$ of effluent. This likely is due to varying degrees of PCR inhibition, perhaps caused by scoria, saprophytic microbial populations, and plant exudates. Extracting DNA from the filter and using this purified DNA for real-time PCR likely would reduce or eliminate inhibition, but introduces a complex, costly step and an added risk of contamination. Direct plating remains the most reliable and sensitive method for detecting $R$. solanacearum in geranium tissue and effluent.

We used only one cultivar of zonal geranium, Designer Dark Red, in these experiments. Just as tomato cultivars respond differently to $R$. solanacearum, different geranium cultivars probably also have different responses. These could include differences in the incidence of latent versus active infections and possibly the overall susceptibility to infection. However, we have observed shedding of $R$. solanacearum from roots of three different geranium cultivars, suggesting that this is a general phenomenon. Overall, we found that the method of effluent collection, filtering, and PCR analysis in geranium production facilities was not highly reliable because not every infected plant sheds detectable numbers of bacteria. Nonetheless, it is probably more sensitive than the existing random single-plant immunostrip testing protocol because it allows testing of pooled samples from many plants. Some promising emerging detection technologies include bioconjugated nanoparticles that can detect a single pathogen cell, and CANARY, which uses modified B cells to detect as few as 50 cells in under $3 \mathrm{~min}(22,28)$. These technologies would allow for greater sensitivity of detection, and could make effluent monitoring an appealing diagnostic approach.

\section{ACKNOWLEDGMENTS}

This research was funded by a United States Department of Agriculture Floral and Nursery Industry Task Force Specific Cooperative Agreement and by the University of Wisconsin-Madison College of Agricultural and Life Sciences. We thank M. Klopmeyer (Ball Horticultural Co., West Chicago, IL) for critical reading of the manuscript; D. Kaplan, P. Berger (APHIS-CPHST, Raleigh, NC), L. Levy, and D. Jones (APHIS-PPQ, Beltsville, MD) for useful discussions; and Ball FloraPlant (West Chicago, IL), Floricultura S.A. (Jalapa, Guatemala), and AgDia, Inc. (Elkhart, IN) for providing research materials.

\section{LITERATURE CITED}

1. Allen, C., Kelman, A., and French, E. R. 2001. Brown rot of potatoes. Pages 11-13 in: Compendium of Potato Diseases, 2nd ed. W. R Stevenson, R. Loria, G. D. Franc, and D. P. Weingartner, eds. American Phytopathological Society, St. Paul, MN

2. APHIS-PPQ. 2004. Minimum Sanitation Protocols, Testing and Sampling Plan for Offshore Production Facilities. USDA-APHIS PPQ Pest Detection and Management Programs, Riverdale, MD.

3. Caruso, P., Gorris, M., Cambra, M., Palomo, J., Collar, J., and Lopez, M. 2002. Enrichment double-antibody sandwich indirect enzymelinked immunosorbent assay that uses a specific monoclonal antibody for sensitive detection of Ralstonia solanacearum in asymptomatic potato tubers. Appl. Environ. Microbiol. 68:3634-3638.

4. Ciampi, L., and Sequeira, L. 1980. Influence of temperature on virulence of race 3 strains of 
Pseudomonas solanacearum. Am. Potato J. 57:307-317.

5. Denny, T. 2006. Plant-pathogenic Ralstonia species. Pages 573-644 in: Plant-Associated Bacteria. S. S. Gnanamanickam, ed. Springer Press, New York.

6. Elphinstone, J. G. 1996. Survival and possibilities for extinction of Pseudomonas solanacearum (Smith) Smith in cool climates. Potato Res. 39:403-410.

7. Elphinstone, J. G. 2005. The current bacterial wilt situation: A global overview. Pages 9-28 in: Bacterial Wilt: The Disease and the Ralstonia solanacearum Species Complex. C. Allen, P. Prior, and A. C. Hayward, eds. American Phytopathological Society Press, St. Paul, MN.

8. Elphinstone, J. G., Hennessey, J., Wilson, J. K., and Stead, D. E. 1996. Sensitivity of different methods for the detection of Ralstonia solanacearum in potato tuber extracts. EPPO Bull. 26:663-678.

9. Fegan, M., and Prior, P. 2005. How complex is the "Ralstonia solanacearum" species complex? Pages 449-461 in: Bacterial Wilt Disease and the Ralstonia solanacearum species complex. C. Allen, P. Prior, and A. C. Hayward, eds. American Phytopathological Society Press, St. Paul, MN.

10. Grimault, V., Anais, G., and Prior, P. 1994. Distribution of Pseudomonas solanacearum in the stem tissues of tomato plants with different levels of resistance to bacterial wilt. Plant Pathol. 43:663-668.

11. Hayward, A. C. 1991. Biology and epidemiology of bacterial wilt caused by Pseudomonas solanacearum. Annu. Rev. Phytopathol. 29:65-87.

12. Hayward, A. C., and Hartman, G., eds. 1994. Bacterial Wilt: The Disease and Its Causative
Organism, Pseudomonas solanacearum. CAB International, Oxon, UK.

13. Hendrick, C., and Sequeira, L. 1984. Lipopolysaccharide-defective mutants of the wilt pathogen Pseudomonas solanacearum. Appl. Environ. Microbiol. 48:94-101.

14. Janse, J. D. 1996. Potato brown rot in western Europe: History, present occurrence and some remarks on possible origin, epidemiology and control strategies. EPPO Bull. 26:679-695.

15. Janse, J. D., Beld, H. E. v. d., Elphinstone, J., Simpkins, S., Tjou-Tam-Sin, N. A. A., and Vaerenbergh, J. v. 2004. Introduction to Europe of Ralstonia solanacearum biovar 2, race 3 in Pelargonium zonale cuttings. J. Plant Pathol. 86:147-155.

16. Ji, P., Allen, C., Sanchez-Perez, A., Jones, J., and Momol, T. 2007. New diversity and diagnostic challenges associated with Ralstonia solanacearum strains in Florida. Plant Dis. 91:195-203.

17. Kelman, A. 1953. The bacterial wilt caused by Pseudomonas solanacearum. N. C. Agric. Exp. Stn. Tech. Bull. No. 99.

18. Kelman, A. 1954. The relationship of pathogenicity of Pseudomonas solanacearum to colony appearance in a tetrazolium medium. Phytopathology 44:693-695.

19. Kelman, A., and Sequeira, L. 1965. Root-toroot spread of Pseudomonas solanacearum. Phytopathology 55:304-309.

20. Lambert, C. D. 2002. Agricultural Bioterrorism Protection Act of 2002: Possession, Use, and Transfer of Biological; Agents and Toxins; Interim and Final Rule. (7 CFR Part 331). Federal Register 67:76908-76938.

21. Nakaho, K., Hiroyochi, I., Takayama, T., and Miyagawa, H. 2004. Distribution and multipli- cation of Ralstonia solanacearum in tomato plants with resistance derived from different origins. J. Gen. Plant Pathol. 70:115-119.

22. Rider, T., Petrovick, M., Nargi, F., Harper, J., Schwoebel, E., Mathews, R., Blanchard, D. Bortolin, L., Young, A., Chen, J., and Hollis, M. 2003. A B cell-based sensor for rapid identification of pathogens. Science 301:213-215.

23. Saddler, G. 2005. Management of bacterial wilt disease. Pages 121-132 in: Bacterial Wilt Disease and the Ralstonia solanacearum Species Complex. C. Allen, P. Prior, and A. C. Hayward, eds. American Phytopathological Society Press, St. Paul, MN

24. Swanson, J. K., Yao, J., Tans-Kersten, J. K., and Allen, C. 2005. Behavior of Ralstonia solanacearum race 3 biovar 2 during latent and active infection of geranium. Phytopathology 95:136-143

25. Weller, S. A., Elphinstone, J. G., Smith, N. C. Boonham, N., and Stead, D. 2000. Detection of Ralstonia solanacearum strains with a quantitative, multiplex, real-time fluorogenic PCR (TaqMan) assay. Appl. Environ. Microbiol. 66:2853-2858.

26. Williamson, L., Hudelson, B. D., and Allen, C. 2002. Ralstonia solanacearum strains isolated from geranium belong to race 3 and are pathogenic on potato. Plant Dis. 86:987-991.

27. Yao, J., and Allen, C. 2006. Chemotaxis is required for virulence and competitive fitness in the bacterial wilt pathogen Ralstonia solanacearum. J. Bacteriol. 188:3697-3708.

28. Zhao, X., Hilliard, L., Mechery, S. J., Wang, Y., Bagwe, R., Jin, S., and Tan, W. 2004. A rapid bioassay for single bacterial cell quantitation using bioconjugated nanoparticles. Proc. Natl. Acad. Sci. USA 101:15027-15032. 